\title{
MORTALITY IN A RURAL ZULU COMMUNITY
}

BY

\author{
F. J. BENNETT*
}

Makerere College, Uganda

Death rates for Native Reserves in South Africa are scarce because there are few places where the population is adequately known. Although notification of births and deaths is compulsory, only a small percentage are reported, and this is especially true of neonatal deaths. Reasons for the non-existence of these records have been discussed by Myburgh (1956), and alternative methods for obtaining death rates by sampling in rural Rhodesia have been described by Shaul (1955) and in South Africa by Sachs (1953). The only death rates for a rural area in South Africa come in fact from Polela District (Kark and Cassel, 1952; Kark and Chesler, 1956; Brookes and Hurwitz, 1957), which is the area discussed in this paper. There are few African reserves where facilities exist for making a diagnosis before death, as it is exceptional for anyone to be admitted to hospital or even seen by a general practitioner, and post mortem examinations are usually reserved for deaths due to unnatural causes. However, an attempt will be made to indicate recent death rates and their trends and causes in Polela.

\section{Population Studied and Methods Employed}

Data were obtained from the Polela Health Centre (Union Health Department), which is situated in Location 2 of Polela District in Southwest Natal. In 1940 this Health Centre began to study the homes around it, using, amongst others, field workers known as Health Assistants, whose duties included routine census work and notification of births and deaths. Barely 800 people were included in the first demographic survey, but by 1958 the group included more than 10,000 people in

\footnotetext{
*Formerly Medical Officer-in-Charge, Polela Health Centre, Natal.
}

approximately 1,000 rural Zulu homes (about twothirds of the location), and these individuals have since been kept under constant surveillance. As the same group has been the subject of numerous studies by Kark, E. (1943), Kark, S. L. (1942, 1943, 1949, 1950, 1951, 1954, 1957), Cassel (1955, 1957), Slome (1956), Jaspan (1950, 1953), Thompson (1954), Mingay (1958), and Hey (1957), only a few of the background details need be given here.

The inhabitants of Polela District are mainly Zulus who have adopted the Baca material culture (which suits the climate), and their homes are situated in $\mathbf{4 5 0}$ square miles of mountainous country traversed by the deep valleys of the Umkomaas River and its tributaries. The climate is temperate with cold winters, and consequently there is no malaria or bilharzia. The Reserve is rapidly becoming over-populated and the land seriously eroded. Thus, one area with 114 homes and 887 people in 1943 had 184 homes and 1,509 people by 1958-an increase of about 70 per cent. in 15 years.

The main crop is maize, but the yield per family is so small that it is seldom sufficient for more than 3 months of each year. The gross overstocking of the pastures with goats and cattle is actually understocking as far as the human need for protein is concerned, and the universal poverty and lack of natural fencing material precludes successful vegetable, legume, or poultry production. So far from ever exporting foodstuffs, as do other rural areas, Polela is unable to support its own population and has to import food. As a result of this situation, more and more men, and recently even women, have been forced to seek work in towns in order to get money for purchasing food. At present, half the men between the ages of $\mathbf{4 0}$ and 50 and about three-quarters 
of the men between the ages of 25 and 40 are away most of the time, and the permanent residents consist mainly of children, adolescents, women, invalids, and senile men. Nevertheless, the migrant men are included in this study because they often return home to die, and should they die elsewhere the circumstances of death are usually known and the effects are felt by the rest of the family. The migrants constantly re-introduce infections such as tuberculosis, amoebiasis, and venereal disease into the Reserve, and their mode of life tends to undermine traditional family and social customs, though comcomplete disruption is prevented by the extensive webs of kinship which bind together the remaining people.

The standard of education and consequently the earning power of the people is low, and ignorance is an important factor in the causation of death. At the present time nearly all the old people are illiterate, and although about two-thirds of the working adults went to school, only 6 per cent. reached Standard 3. Nowadays approximately 85 per cent. of children are attending school by the age of 13 and nearly 20 per cent. have already reached or passed Standard 3 at that age. As one-third of the population is now of school age this fact is already affecting the mortality rates. A small but ever-growing body (at present 2 per cent.) of Africans have obtained professional qualifications and are working in the Reserve as health workers, teachers, or ministers of religion. They are a force behind the attempts to raise the standard of living and diminish the death rate. Heathenism in Africa is closely associated with lack of education and adherence to traditional beliefs and remedies, and although Polela is predominantly Catholic, about one-sixth of the homes are still heathen and one-tenth of the population still refuses medical treatment on religious grounds.

In short, poverty, migrancy, ignorance, and malnutrition are rife in Polela and all of these are aggravated by tribal and religious beliefs, as in other African Reserves. To many of the people themselves this study would be pointless, for to them death is usually due to bewitchment and is usually announced by the statement, "They have killed him".

\section{Census of Population (Table I)}

According to a census taken in May, 1958, there were 10,607 people in the study group, 5 per cent. of whom were 59 years of age or older and 37 per cent. under 10 years. There were slightly more females $(5,499)$ than males $(5,106)$.
TABLE I

CENSUS OF POPULATION STUDIED, INCLUDING TEMPORARY MIGRANTS (13.5.58)

\begin{tabular}{c|c|c|c}
\hline \multirow{2}{*}{ Date of Birth } & \multicolumn{2}{|c|}{ Sex } & \multicolumn{1}{c}{$\begin{array}{c}\text { Per cent. of } \\
\text { Population }\end{array}$} \\
\cline { 2 - 2 } & Male & Female & \\
\hline -1879 & 21 & 41 & $0 \cdot 58$ \\
$1880-1889$ & 64 & 79 & $1 \cdot 34$ \\
$1890-1899$ & 142 & 187 & $3 \cdot 10$ \\
$1900-1909$ & 286 & 348 & $5 \cdot 97$ \\
$1910-1914$ & 202 & 214 & $3 \cdot 92$ \\
$1915-1919$ & 272 & 259 & $5 \cdot 00$ \\
$1920-1924$ & 300 & 374 & $6 \cdot 35$ \\
$1925-1929$ & 336 & 430 & $7 \cdot 22$ \\
$1930-1934$ & 418 & 474 & $8 \cdot 41$ \\
$1935-1939$ & 493 & 518 & $9 \cdot 53$ \\
$1940-1944$ & 525 & 504 & $9 \cdot 70$ \\
$1945-1949$ & 696 & 663 & $12 \cdot 81$ \\
$1950-1954$ & 802 & 818 & $15 \cdot 27$ \\
1955 & 186 & 169 & $3 \cdot 34$ \\
1956 & 168 & 159 & $3 \cdot 08$ \\
1957 & 155 & 189 & $3 \cdot 24$ \\
1958 & 48 & 67 & $1 \cdot 08$ \\
\hline$\ldots$ & 5,106 & 5,499 & 100 \\
\hline
\end{tabular}

Death Rates, 1945-56

Comparison of three 2-year periods between 1945 and 1956 (Table II) revealed a reduction in the death rate which was greatest for deaths between 1 month and 1 year and least for neonatal deaths and stillbirths. The reasons for the changes between 1945 and 1951 have been discussed by Kark and Cassel (1952), who attributed them more to health education and preventive measures by a communityorientated team than to the curative facilities available.

TABLE II

DEATH RATES IN THREE PERIODS BETWEEN 1945 AND 1956

\begin{tabular}{|c|c|c|c|c|c|}
\hline Period .. & .. & $1945-6$ & $1950-1$ & $1955-6$ & $\begin{array}{l}\text { Approximate } \\
\text { Percentage } \\
\text { Reduction } \\
\text { in Mortality } \\
\text { over } 10 \mathrm{yrs}\end{array}$ \\
\hline \multicolumn{2}{|c|}{$\begin{array}{l}\text { Total Population (average } \\
\text { for 2-year period) }\end{array}$} & 5,963 & 8,015 & 10,024 & \\
\hline \multicolumn{2}{|l|}{ Total Live Births } & 426 & 624 & 720 & \\
\hline \multicolumn{2}{|c|}{$\begin{array}{c}\text { Infant Mortality Rate per } \\
1,000 \text { Live Births }\end{array}$} & 202 & 106 & 86 & $57^{*}$ \\
\hline \multicolumn{2}{|c|}{ 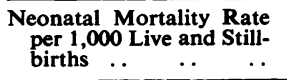 } & 54 & 40 & 50 & 7 \\
\hline \multicolumn{2}{|c|}{$\begin{array}{c}\text { Stillbirth Rate per } 1,000 \\
\text { Total Population } \\
\text {.. }\end{array}$} & 36 & 40 & 31 & 14 \\
\hline $\begin{array}{c}\text { General Death } \\
\text { Rate per 1,000 } \\
\text { Total } \\
\text { Population } \\
\text { by Age (yrs) }\end{array}$ & $\begin{array}{c}0-4 \\
5-14 \\
15-34 \\
35+ \\
\text { All ages }\end{array}$ & $\begin{array}{r}60 \\
4 \\
6 \\
30 \\
24\end{array}$ & $\begin{array}{r}23 \\
3 \\
5 \\
23 \\
16\end{array}$ & \begin{tabular}{r|}
18 \\
2 \\
4 \\
22 \\
12
\end{tabular} & $\begin{array}{l}70 \\
50 \\
33 \\
27 \\
50\end{array}$ \\
\hline
\end{tabular}

* Reduction in the death rate for ages 1 to 12 months $=76$ per cent.

Although a pre-school health programme has been operating for the last 10 years, and, generally speaking, earlier use is also made of its steadily improving 
services, it is probably that the fall in the death rate for the 1 to 5 -year-old group was in fact due to the well-received and intensive welfare service, which aimed at improving both the state of nutrition and the immunity of the baby up to the age of 2 years and also the mothers' knowledge and technique of childrearing.

\section{Cohort Analysis of Deaths}

The precise number of people born in each year is not readily available, but an analysis of the 1945-46 and 1955-56 deaths for 10 cohorts suggests that there has been slight decrease in the death rate, which is greater for men born before 1880 than for any other group. It is, however, noticeable that, for women born between 1925 and 1929, the 1955-56 death rate was lower than that for women born between 1930 and 1934. The rapid extinction of the older age cohorts is also shown in Table III.

TABLE III

DEATH RATES PER THOUSAND FOR TEN COHORTS

\begin{tabular}{|c|c|c|c|c|c|}
\hline \multirow{2}{*}{$\frac{\text { Sex }}{\text { Period }}$} & \multirow{2}{*}{$\frac{\therefore}{\cdots}$} & \multicolumn{2}{|c|}{ Male } & \multicolumn{2}{|c|}{ Female } \\
\hline & & $1945-6$ & $1955-6$ & $1945-6$ & $1955-6$ \\
\hline Cohort & $\begin{array}{l}-1880 \\
-1889 \\
-1899 \\
-1909 \\
-1914 \\
-1919 \\
-1924 \\
-1929 \\
-1934 \\
-1939\end{array}$ & $\begin{array}{r}129.7 \\
47.7 \\
17.3 \\
27.7 \\
10.3 \\
6.4 \\
7.2 \\
4.1 \\
1.3 \\
1.4\end{array}$ & $\begin{array}{r}205.3 \\
-50.8 \\
-32.7 \\
-12.6 \\
-4.1 \\
-10.6 \\
-4.7 \\
=7.1 \\
=0.0 \\
=3.0\end{array}$ & $\begin{array}{r}62.5 \\
37.2 \\
17.1 \\
12.2 \\
12.1 \\
12.7 \\
9.1 \\
1.3 \\
2.6 \\
10.6\end{array}$ & $\begin{array}{r}86 \\
-52.8 \\
-35.8 \\
-18.0 \\
-6.7 \\
-11.3 \\
-2.7 \\
-3.5 \\
-6.0 \\
2.8\end{array}$ \\
\hline
\end{tabular}

The oblique lines indicate corresponding death rates for two adjacent cohorts.

Since 1945 there has been a change in the order of the age groups when ranked according to their percentage contribution to the annual deaths (Table IV). By 1955 the main contribution to the death rate was coming from old people, but 10 years previously it had come from infant deaths.

TABLE IV

PROPORTIONAL AGE DISTRIBUTION OF DEATHS (1945 AND 1955)

\begin{tabular}{c|c|c|c|c|c|c}
\hline & \multicolumn{3}{|c|}{1945} & \multicolumn{3}{c|}{1955} \\
\cline { 2 - 7 } $\begin{array}{c}\text { Age } \\
\text { (yrs) }\end{array}$ & $\begin{array}{c}\text { No. of } \\
\text { Deaths }\end{array}$ & $\begin{array}{c}\text { Per cent. } \\
\text { of Total } \\
\text { for Year }\end{array}$ & Rank & $\begin{array}{c}\text { No. of } \\
\text { Deaths }\end{array}$ & $\begin{array}{c}\text { Per cent. } \\
\text { of Total } \\
\text { for Year }\end{array}$ & Rank \\
\hline $\begin{array}{c}\text { Under } 1 \\
1-5\end{array}$ & 37 & 32 & 1 & 28 & 24 & 2 \\
$\begin{array}{c}6-18 \\
19-55\end{array}$ & 27 & 23 & 25 & 21 & 19 & 4 \\
Over 55 & 19 & 23 & 3 & 25 & 5 & 5 \\
\hline Total & 116 & 100 & & 38 & 32 & 1 \\
\hline
\end{tabular}

\section{Causes of Death}

Before 1949 very few causes of death were recorded, presumably because so few people were receiving medical attention at that time. Reference is made, however, to whooping cough, often associated with "malignant" malnutrition" (kwashiorkor), as an important cause of death in 1945. In the same year a survey of twenty homes in which deaths had occurred showed that six deaths were probably due to tuberculosis, and prematurity associated with multiple births is cited in one early report as an important cause of neonatal death. A more detailed analysis of the causes of death was made for the years 1950-51, but this dealt only with adolescents and adults. At this time the commonest diagnoses were tuberculosis, dysentery, violence, and hypertensive heart failure.

Known and unknown causes of death for the period 1949-1953 are shown in Table V.

TABLE V

CAUSES OF DEATH IN TWO SUCCESSIVE PERIODS 1949-51 AND 1952-53

\begin{tabular}{|c|c|c|c|c|}
\hline \multirow{2}{*}{$\begin{array}{l}\text { Main Category } \\
\text { (International } \\
\text { Classification) }\end{array}$} & \multirow{2}{*}{ Sub-Category } & \multicolumn{2}{|c|}{ Period } & \multirow{2}{*}{ Tota } \\
\hline & & $\overline{1949-51}$ & $\overline{1952-53}$ & \\
\hline $\begin{array}{l}\text { I Infective } \\
\text { Diseases }\end{array}$ & $\begin{array}{l}\text { Leprosy } . . \\
\text { Tuberculosis } \quad . \\
\text { Syphilis } \because \\
\text { Intestinai Infec- } \\
\text { tions } \quad . \\
\text { Other Infections }\end{array}$ & $\begin{array}{r}50 \\
5 \\
41 \\
8\end{array}$ & $\begin{array}{r}1 \\
62 \\
2 \\
43 \\
2\end{array}$ & $\begin{array}{r}1 \\
92 \\
7 \\
84 \\
10\end{array}$ \\
\hline II Neoplasms & - & 7 & 5 & 12 \\
\hline $\begin{array}{r}\text { VI Diseases of } \\
\text { Central } \\
\text { Nervous } \\
\text { System }\end{array}$ & $\begin{array}{l}\text { Cerebral Abscess } \\
\text { Thrombosis and } \\
\text { Haemorrhage } \\
\text { Epilepsy .. } \quad . .\end{array}$ & $\begin{array}{l}1 \\
2 \\
2\end{array}$ & $\begin{array}{c}- \\
2 \\
1\end{array}$ & $\begin{array}{l}1 \\
4 \\
3\end{array}$ \\
\hline $\begin{array}{c}\text { VII Cardiovascu- } \\
\text { lar Diseases }\end{array}$ & $\begin{array}{cc}\text { Congestive } & \text { Heart } \\
\text { Failure } & \ldots\end{array}$ & 17 & 27 & 44 \\
\hline $\begin{array}{c}\text { VIII Respiratory } \\
\text { Diseases }\end{array}$ & $\begin{array}{l}\text { Pneumonia } \\
\text { Other Unspecified }\end{array}$ & $\begin{array}{l}11 \\
10\end{array}$ & $\begin{array}{r}9 \\
24 \\
\end{array}$ & $\begin{array}{l}20 \\
34 \\
\end{array}$ \\
\hline XI Pregnancy & $\begin{array}{l}\text { Puerperal Sepsis } \\
\text { Abortion... } \\
\text { Post-partem } \\
\text { Haemorrhage }\end{array}$ & $\begin{array}{c}-1 \\
1\end{array}$ & $\frac{1}{-}$ & $\begin{array}{l}1 \\
1 \\
1\end{array}$ \\
\hline $\begin{array}{c}\text { XIV Congenital } \\
\text { Defects }\end{array}$ & & 2 & - & 2 \\
\hline $\begin{array}{c}\text { XV Diseases of } \\
\text { Infancy }\end{array}$ & $\begin{array}{l}\text { Kwashiokor } \\
\text { Prematurity and } \\
\text { Birth Injury }\end{array}$ & $\begin{array}{l}20 \\
16\end{array}$ & $\begin{array}{r}9 \\
26\end{array}$ & $\begin{array}{l}29 \\
42\end{array}$ \\
\hline XVII Accidents & $\begin{array}{c}\text { Violence and } \\
\text { Injury }\end{array}$ & 13 & 18 & 31 \\
\hline XVI Ill-defined & $\begin{array}{l}\text { Senility ... } \\
\text { Unknown }\end{array}$ & $\begin{array}{r}2 \\
186 \\
\end{array}$ & $\overline{96}$ & 282 \\
\hline Totals & & 375 & 328 & 703 \\
\hline & $\begin{array}{lll}1949 & 6,6 \\
1950 & 7,4 \\
1951 & 8,5\end{array}$ & & $\begin{array}{l}8,962 \\
9,206\end{array}$ & \\
\hline
\end{tabular}


Of the 421 deaths of which the cause was known 250 ( 59 per cent. of known causes and 36 per cent. of all deaths) were due to infections - the most common being tuberculosis and other respiratory (146) and gastro-intestinal (84) disorders; ten other infections (mainly spread by contact) formed a negligible group (only $2 \cdot 3$ per cent.). Vector-borne diseases do not appear in the list but it is possible that in some cases tuberculosis, respiratory disease, and diarrhoea were transmitted from animals, the most likely being cattle, poultry, and rats. No less than 40 per cent. of deaths during these 5 years were due to unknown causes.

The more detailed records for the period 1955-58 allow sub-division by age and cause of death (see Tables VI and VII). During this period $14 \cdot 1$ per cent. of deaths occurred before the age of one month, a further 24.5 per cent. before the age of 6 years, and a further 28.8 per cent. between 6 and 55 years. Deaths at older ages represented 32.6 per cent. of all deaths.

TABLE VI

CAUSES OF DEATH, 1955-58, IN INFANTS UNDER 5 YEARS OLD

\begin{tabular}{|c|c|c|c|c|c|c|}
\hline \multirow{2}{*}{\multicolumn{3}{|c|}{ Cause of Death }} & \multirow{2}{*}{$\begin{array}{c}\text { Still- } \\
\text { births }\end{array}$} & \multicolumn{3}{|c|}{ Deaths } \\
\hline & & & & $\begin{array}{l}\text { Neo- } \\
\text { natal }\end{array}$ & $\begin{array}{l}1 \text { to } 12 \\
\text { mths }\end{array}$ & $\begin{array}{l}1 \text { to } 5 \\
\text { yrs }\end{array}$ \\
\hline \multicolumn{3}{|c|}{ 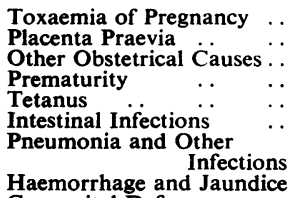 } & $\begin{array}{r}2 \\
1 \\
7 \\
4 \\
- \\
- \\
- \\
= \\
= \\
= \\
= \\
- \\
\end{array}$ & $\begin{array}{r}1 \\
2 \\
5 \\
26 \\
3 \\
7 \\
4 \\
3 \\
1 \\
- \\
\\
1 \\
- \\
\overline{2}\end{array}$ & $\begin{array}{l}\bar{Z} \\
\bar{Z} \\
\overline{1} \\
14 \\
\frac{10}{2} \\
\frac{10}{2} \\
\frac{10}{9} \\
\overline{9}\end{array}$ & $\begin{array}{l}\bar{Z} \\
\bar{Z} \\
\overline{-} \\
\overline{18} \\
5 \\
1 \\
\overline{26} \\
3 \\
6 \\
3 \\
2 \\
1 \\
1 \\
14\end{array}$ \\
\hline Total & $\cdots$ & . & 34 & 75 & 50 & 80 \\
\hline
\end{tabular}

Stillbirths.-The Wassermann reaction, which was done in 27 out of the 34 women whose babies were stillborn, was negative in all but one, who had received two courses of penicillin during pregnancy. In three of the seven women whose serology was unknown there were well-defined reasons for the stillbirth; it is thus unlikely that syphilis could have contributed to more than 20 per cent. of stillbirths, and a more likely figure is 5 per cent. That syphilis had previously been a more important factor is evident from a 1949-1953 estimation that 8.9 per
TABLE VII

CAUSES OF DEATH, 1955-58, IN PERSONS OVER 5 YEARS OLD

\begin{tabular}{|c|c|c|c|c|c|c|}
\hline \multirow{2}{*}{\multicolumn{4}{|c|}{ Diagnostic Group }} & \multicolumn{3}{|c|}{ Age Group (yrs) } \\
\hline & & & & $5-18$ & $19-55$ & Over 55 \\
\hline \multicolumn{3}{|c|}{$\begin{array}{l}\text { I Tuberculosis } \\
\text { Intestinal Infections } \\
\text { Other Infective Diseases }\end{array}$} & $\begin{array}{l}\cdots \\
\cdots \\
\cdots\end{array}$ & $\begin{array}{l}3 \\
2 \\
4\end{array}$ & $\begin{array}{r}31 \\
6 \\
-\end{array}$ & $\begin{array}{r}11 \\
5 \\
1\end{array}$ \\
\hline \multicolumn{2}{|l|}{ II Neoplasms } & .. & . & - & 7 & 13 \\
\hline \multicolumn{3}{|c|}{ VI Epilepsy } & $\begin{array}{l}\cdots \\
\cdots\end{array}$ & - & $\begin{array}{l}3 \\
3\end{array}$ & $\begin{array}{l}1 \\
6\end{array}$ \\
\hline \multicolumn{3}{|c|}{ VII Cardiovascular Disease } & $\cdots$ & 2 & 19 & 35 \\
\hline \multicolumn{3}{|c|}{$\begin{array}{l}\text { VIII Pneumonia . . } \ldots \\
\text { Other Respiratory Disease }\end{array}$} & $\cdots$ & $\begin{array}{l}1 \\
1\end{array}$ & $\overline{7}$ & $\begin{array}{l}8 \\
9\end{array}$ \\
\hline \multicolumn{2}{|c|}{ IX Hepatic Cirrhosis } & $\cdots$ & $\cdots$ & - & 1 & 1 \\
\hline X Uraemia & $\cdots$ & $\cdots$ & $\cdots$ & - & - & 1 \\
\hline XI Pregnancy & $\cdots$ & $\cdots$ & $\cdots$ & - & 2 & - \\
\hline \multicolumn{2}{|c|}{ XVII Violence and Injury } & $\cdots$ & $\cdots$ & 4 & 19 & 9 \\
\hline $\begin{array}{c}\text { XVI Senility } \ldots \\
\text { Unknown }\end{array}$ & $\cdots$ & $\cdots$ & $\ddot{\cdots}$ & $\overline{7}$ & $\overline{31}$ & $\begin{array}{l}11 \\
62\end{array}$ \\
\hline \multirow{3}{*}{ Total Deaths } & Male & $\cdots$ & $\cdots$ & 14 & 62 & 77 \\
\hline & Female & . & . & 10 & 67 & 96 \\
\hline & Total & . & . & 24 & 129 & 173 \\
\hline
\end{tabular}

cent. of pregnant women with positive serological tests had stillbirths, compared with only 3.4 per cent. of those with negative serological tests (Kark and Chesler, 1956). In the period 1957 to 1958 , only two of the 21 women who had stillbirths had not attended ante-natal sessions at Polela Health Centre, and during these years 80 per cent. of all pregnant women attended for routine ante-natal care. For 20 per cent. of the stillbirths obstetrical complications were anticipated and the mother was delivered in hospital. According to the figures shown in Table II, there has been little reduction in stillbirths over the years, in spite of an increasing acceptance by the women of ante-natal care and skilled delivery. As great emphasis has been laid on maternal nutrition and education, and as diets have frequently been supplemented with dried milk powder, vegetables, and vitamins, one is left with the conviction that the universal poverty, soil erosion, maize diet, and consequent life-long malnutrition are the ineradicable basic factors in the majority of stillbirths. The relationship between maternal nutrition and foetal and neonatal wastage has been summarized by Stearns (1958) and Hepner (1958), who have produced a strong case for the idea that maternal malnutrition constitutes an important causal factor in stillbirths. In Polela these were often associated with premature labour and uterine inertia, and it is 
possible that nutritional factors accounted for as many as $\mathbf{2 5}$ out of the $\mathbf{3 4}$ recorded stillbirths, though a high proportion of unknown causes is a feature of stillbirth investigations in other countries.

If left to themselves, the Zulus in Polela usually follow a policy of non-interference during labour, but there is a tendency to advise premature bearing down if labour is not progressing rapidly. This may be a contributory cause of stillbirth, but on the whole the traditional native delivery techniques do not appear to have been more lethal than the more civilized methods, except in complicated cases, where skilled delivery has been shown to be definitely superior.

Neonatal Deaths.-Some of the causes of neonatal deaths could have been minimized, particularly those associated with the premature delivery of twins. "Prematurity" accounted for one-third of neonatal deaths. It was associated with multiple pregnancy in half, and maternal malnutrition was probably an important factor in these and other cases. During 1957 and 1958 there were twenty pairs of twins from 703 confinements, an incidence of one in 35 , which is more than twice the twin rate found at Guy's Hospital. At least one-third of the neonatal deaths were due to infections, one-quarter of which gained entrance through the umbilical stump. The apparent rarity of respiratory infections in the first month of life may be due to the fact that fulminating cases are not readily appreciated in premature babies and therefore tend to fall into the unknown or premature groups. Continuous education at the Health Centre has almost completely eradicated the original practice of feeding babies with gruel during the first few days of life, and nowadays initially unsupplemented breast-feeding is the rule. The incidence of gastro-enteritis is consequently low in the neonatal period, and it is worthy of note that two of the seven cases occurred in premature infants who were artificially fed in hospital. The unknown causes of death in the neonatal period probably include a high proportion of congenital abnormalities and birth injuries.

Other Infant Deaths.-Gastro-enteritis was the most important cause of death between birth and 12 months (31 per cent. of this group) and was often a complicating factor in the 26 per cent. of deaths ascribed to marasmus and kwashiorkor. Intestinal infections were commonest in February and March, which besides being late summer or early autumn months were also the times of child neglect through the mothers absence in the fields for weeding. In
Polela illegitimacy did not appear to be an important factor in infant deaths, and only one mother conceived her child in a town, returned to the Reserve for her confincment, and then returned to the town, leaving the baby with its milkless grandparents. But it is likely that comparable situations will be more frequent in the future.

About one-third of the deaths in this group were of first babies, suggesting that lack of experience in recognizing the presence of infection or the value of European medicine were acting as a contributory cause of death. Barely half the children who might have come to the Clinic were actually brought before death-the main reasons for not seeking help being distance from the Health Centre or adherence of the parents to religious sects prohibiting medical treatment.

The frequency of bronchopneumonia as a cause of death in this group was not a surprise, and some of the deaths due to unknown causes were doubtless due to respiratory infections. Marasmus from failure to establish or continue breast-feeding was an equally important cause of death, as it was seldom possible for the mother or guardian to obtain or afford sufficient cow's milk or other source of protein. Two of the deaths in this category were due to the mother's death, and in other cases breast abscess or cracked nipples (relatively common in Polela, but apparently rare in Natal hospital populations) had fatal consequences. Boys contributed 57 per cent. of deaths in this age group.

Deaths between 1 and 5 years.-Kwashiorkor and intestinal infections were the commonest causes of death in the 1 to 5-year-old group, and most deaths occurred in January, February, and March. As only seventeen cases of kwashiorkor were seen (or known to field workers) at the Health Centre in 1956, compared with 53 and 61 respectively in the two following years, it is clear that the incidence is rising through increasing protein shortage, though the case mortality is decreasing, through improved and more prolonged treatment. There were three peak incidences of kwashiorkor in Polela district:

(1) March-April (probably due to maternal deprivation because of weeding duties in February);

(2) June-August (the winter months associated with extreme cow's milk shortage);

(3) November-December (seasonal duties and the peak pellagra months which might lead to reduction in human milk supplies). 
Provision of more subsidized dried milk powder or any other suitable source of protein appears to be the only solution to this particular tragedy: at present milk can only be prescribed from the Health Centre as a curative medicine and is not available prophylactically - a strange position for a disease which can be recognized by gingering hair and failure in growth long before it could be described as "malignant malnutrition". Previously this condition was attributed to ignorance and faulty weaning, but these reasons are unimportant to-day, as the mothers are now well informed and would give their babies any protein that was available. A high incidence of gasto-enteritis is only to be expected in a community with low standards of hygiene, and there were probably several such cases as well as cases of kwashiorkor among the deaths from unknown causes.

Table II shows that deaths between 1 and 5 years of age declined rapidly between the first two periods but only slightly between the second and third periods. The rapid decline can probably be ascribed to the improvements which were introduced with the Health Centre, but there remain many social and economic causes of death which are not amenable to medical treatment, including disrupted family life and lack of opportunity to earn a reasonable salary, and it is these which appear to be root causes of kwashiorkor in South Africa.

Later Deaths.-For children over 5 years of age serious afflictions, such as a bolt of lightning, massive necrosis of the liver, or a fulminating meningitis seemed to be required to cause death; it is not until after the age of 18 that the diseases of young persons-tuberculosis and rheumatic fever-begin to feature markedly in the mortality statistics.

There were 42 deaths of persons between the ages of 19 and 55 which occurred away from home, either in hospital or in distant towns or farms. Nevertheless, the predominantly male deaths which can be ascribed to migrant habits (viz. traffic accidents, amoebiasis, and tuberculosis) were balanced by female deaths associated with pregnancy, making almost equal numbers of deaths in the two sexes. Pulmonary tuberculosis was the greatest single cause of death in this age group; it is hoped that when antibiotic treatment becomes more widely available and accepted the mortality rate will be reduced, though a radical alteration of socio-economic conditions may be needed to reduce the morbidity rate. Congestive cardiac failure in persons under the age of $\mathbf{5 5}$ was usually due to rheumatic heart lesions or to hypertension, often associated with nephritis and pyelonephritis.

The one-quarter of deaths from unknown causes were equally divided between the two sexes and probably included several due to tuberculosis, cardiac failure, and pneumonia.

After the age of 55 certification of causes of death was less satisfactory, and no less than 60 per cent. of the individuals who died were not seen in their last illness. Sufficient was known about some of these cases to enable them to be placed in one of the diagnostic categories (e.g. "probably congestive heart failure"). There remained, however, 35 per cent. of deaths which were due to unknown causes or, more often, occurred in individuals who had never been seen by a doctor or Health Centre Assistant. European patients usually consult their doctors more frequently as they get older, but aged Bantu usually go to herbalists and diviners. It is often difficult to transport an aged ill person, and old women are rarely able to travel on horseback. Hence the percentage of cases seen before death in each locality was proportional to the accessibility of the area by the Health Centre ambulance. Polela Health Centre was exceptional in seeing as many as 40 per cent. of the old people before death, and this relatively high proportion is the result of years of community health education in this district.

Tuberculosis, respiratory infections, carcinoma, and cardiac failure appear to be the commonest causes of death after the age of 55, and several of the deaths due to unknown causes probably fall into this group.

The basic causes of the heart failure and respiratory disease are obscure, and further research is needed to recognize the roles of chronic bronchitis, malnutrition, and degenerative vascular processes. That malnutrition plays a part in some of these deaths is evident from the fact that the peak incidence of deaths from unknown causes and cardiac failure occurs in the peak pellagra and starvation months of October, September, November, and December. These are also months when the aged are left alone at home whilst the able-bodied adults do the ploughing. Numerous obscure cases of diffuse pulmonary fibrosis, asthma, and bronchitis are seen in elderly people in Polela District; this makes one wonder how many are due to snuff-taking, to repeated exposure to cold in moving from one hut to another, to smoke-filled huts, or to the soot which filters down from thatched roofs. 
Only one death due to coronary thrombosis was recorded, but it is possible that there were others in the "never seen" or "unknown cause" groups. As Bantu who have spent most of their working life in towns prefer to end their days in the Reserves, the post mortem surveys of town populations (which have revealed relatively few cases of coronary atheroma, diffuse myocardial fibrosis, or endomyocardial fibrosis) do not necessarily exclude these as causes of death in South African Bantu. During the last 4 years at least 4 per cent. of deaths in Polela in old persons were certainly due to hypertension, and there were probably more among the "probable cardiac failures" and "unknowns". But the precise role of chronic nephritis or chronic renal infection in the aetiology of hypertension in this part of the world is still unknown. The very few, frail Africans who survive to 90 do so in spite of years of toil, starvation, and repeated infectious processes.

\section{Secular Trend of Deaths Due to Unknown Causes}

In the period 1949-1953 no less than $40 \cdot 1$ per cent. of deaths were due to unknown causes, compared with only 27 per cent. in the period 1955-58. This decline is due to better diagnostic facilities, better attendance at the Health Centre (the number of persons who have never visited the Health Centre is steadily diminishing each year), increased home visiting by the Health Centre staff, and wider use of hospital facilities in difficult cases. But there is still room for improvement, especially at the extremes of life. During the period 1955-58 deaths due to unknown causes represented just under 30 per cent. of neonatal deaths, less than 20 per cent. of deaths between 1 month and 5 years, about 25 per cent. of deaths between 6 and 55 years, and over 35 per cent. for deaths in older persons.

Place of Death.-During the year 1955 there were deaths affecting 106 homes, and the following year 15 per cent. of these homes had a second or third death. These later deaths were often due to the same causes as the earlier death in the same house (e.g. tuberculosis, diarrhoea, premature twins, mismanagement of small children by a tribal grandmother, refusal to seek medical treatment for religious reasons) or to related causes (e.g. death of a mother followed by starvation of a baby), and for 7 per cent. of all deaths in 1956 the cause could be traced to a similar event in the previous year. Deaths in neighbouring households could also be traced to similar causes, but here there were usually several common factors operating, such as distance from the Health Centre, religious prejudice, and a common source of infection, notably a case of tuberculosis or infected food. The absence of major epidemics of typhoid and diphtheria in Polela is characteristic of this region and is probably due to the continuous medical surveillance of the community by the Health Centre. The occurrence of epidemics in neighbouring districts is evidence that the social and environmental situation is otherwise favourable for such outbreaks.

In 1957 there were 144 deaths, 95 in the patient's own home, fifteen in hospital, fourteen in other houses in the district (including herbal and nursing homes), nine in distant places, six out of doors (drowning and road accidents), and five at the Health Centre (brought in moribund). Compared with other Reserves in South Africa, the Polela figure of 10 per cent. deaths in hospital is an exceptionally high one.

Social Repercussions of Death.-Approximately one-third of the men who died during the period of study had, on average, four dependants, and three-quarters of the women left small children who ran a severe risk of dying from neglect or starvation. These figures give some indication of the serious repercussions of the premature death of an adult in this and other African Reserves.

In conclusion, it must be emphasized that all these statistics are derived from a Reserve in which the people have and use exceptionally good preventive and curative medical services. It is sobering to speculate on the conditions that prevail in Reserves with the same economic, social, and agricultural situation but no medical and social welfare facilities.

\section{SUMmaRY}

Death rates and causes of death are presented for a rural Zulu community. Attention is drawn to the large number of deaths from unknown causes, and to the work which is being done to obtain better vital statistics for Bantu populations.

\section{REFERENCES}

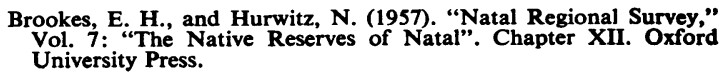
ive Reserves of Natal". Chapter XII. Oxford University Press. 
Cassel, J. (1955). "A Comprehensive Health Program among South African Zulus," in "Health, Culture, and Community", ed. B. D. Paul, pp. 15-41. Russell Sage Foundation, New York

(1957). Amer. J. publ. Hlth, 47, 732.

Hepner, R. (1958). J. Amer. med. 4 ss. 168, 1774.

Hey, P. (1957). Thesis for Ph.D. (Education) - Natal University.

Jaspan, M. A. (1950). Thesis for Ph.D. (Anthropology), London University.

(1953). "A Sociological Case Study-Communal Hostility to Imposed Social Change in South Africa", in "Approaches to Community Development", ed P. Ruopp, p. 97. Van Hoeve, The

Hague.
Kark, E. (1943). S. Afr. J. med. Sci. 8, 35.

Kark, S. L. (1942). S. Afr. med. J., 16, 197.

Kark, S. L. (1942). $S$. Afr. (1949). S. Afr. med. J., 23, 77.

Kark, S. L. (1950). Leech, 21. 23.

(1951). "Health Centre Service-A South African Experiment in Family Health and Medical Care", in "Social Medicine", ed. E. H. Cluver, pp. 661-760. Central News Agency, South Africa. (1954). Thesis. University of Witwatersrand.

(1957). Med. Proc., 3, 330; 404.

- and Cassel, J. (1952), S. Afr. med. J., 26, 101.

and Chesler, J. (1956). S. Afr. J. Lab. clin. Med., 2, 134.

Mingay, R. (1958). Thesis for M.Sc. (Psychology), Natal University.

Myburgh, C. A. L. (1956). Cent. Afr. J. Med., 2, 155.

Sachs, S. B. (1953). S. Afr. med J., 27, 681.

Shaul, J. R. H. (1955). Cent. Afr. J. Med., 1, 83; 120; 145; 246.

Slome, C. (1956). J. Pediat., 49, 550

Stearns, G. (1958). J. Amer. med. Ass., 168, 1655

Thompson, V. (1954). Thesis for M.A. (Psychology), Natal Universit y 